\title{
EKSPERIMENTASI MODEL PEMBELAJARAN \\ KOOPERATIF TIPE TEAMS GAMES TOURNAMENT \\ DENGAN PETA KONSEP PADA POKOK BAHASAN \\ TRIGONOMETRI DITINJAU DARI EMOTIONAL SPIRITUAL QUOTIENT DAN KONSEP DIRI SISWA SMA/MA KELAS XI IPA SE KABUPATEN BANYUMAS
}

\author{
Nastiti Rahayu $^{1}$, Budi Usodo ${ }^{2}$,dan Mardiyana ${ }^{3}$ \\ ${ }^{1,2,3}$ Prodi Magister Pendidikan Matematika, PPs Universitas Sebelas Maret Surakarta
}

\begin{abstract}
This research was conducted to find out: (1) which produces better mathematics achievement: students who were given TGT cooperative learning with mind mapping, TGT cooperative learning, or conventional learning; students who have high emotional spiritual intelligence or low one; students who have a positive or negative self-concept. and (2) which is better, the mathematics achievement of students in each category of spiritual emotional intelligence (high or low) and the category of self-concept (positive or negative) on the TGT with mind mapping, TGT cooperative learning, and conventional learning. This study used a quasi-experimental study with a factorial design $3 \times 2 \times 2$. The population in this study were all students of Science Second Grade Students of senior high schools in Banyumas Regency in the Academic Year of 2012/2013. The hypothesis test used three-way analysis of variance with unbalanced cell. Based on the analysis, we concluded as follows. (1) The mathematics achievement of students given TGT learning model with mind mapping was better than students given TGT learning model and the conventional model of learning. However, there was no difference in achievement between students given TGT learning models with conventional learning model; there was no difference in mathematics achievement of students with high emotional spiritual intelligence with students with low emotional spiritual intelligence; the mathematics achievement of students with positive selfconcepts better than students with a negative self-concept. (2) In every model of learning, students with high emotional spiritual intelligence always provide a better learning achievement than students with low emotional spiritual intelligence. In the learning model TGT with mind mapping, students with a positive self-concept provided better mathematics achievement than students with a negative self-concept, while in the TGT and conventional learning model, there was no difference in achievement between students with a positive self-concept and students with negative self-concept.
\end{abstract}

Key words: Mathematics Learning Achievement, TGT, Mind Mapping, ESQ, Self Concept

\section{PENDAHULUAN}

Pembelajaran Matematika umumnya didominasi oleh pengenalan rumus-rumus serta konsep-konsep secara verbal, tanpa ada perhatian yang cukup terhadap pemahaman siswa. Pembelajaran matematika sering diinterpretasikan sebagai aktivitas utama yang dilakukan guru, yaitu guru mengenalkan materi, mungkin mengajukan satu atau dua pertanyaan, dan meminta siswa yang pasif untuk aktif dengan memulai melengkapi latihan dari buku teks, pelajaran diakhiri dengan pengorganisasian yang baik dan pembelajaran selanjutnya dilakukan dengan skenario yang serupa. 
Kondisi di atas tampak lebih parah pada pembelajaran trigonometri. Sebagian siswa tidak mengetahui mengapa dan untuk apa mereka belajar konsep-konsep trigonometri, karena semua yang dipelajari terasa jauh dari kehidupan mereka sehari-hari. Siswa hanya mengenal trigonometri dari apa yang digambar oleh guru di depan papan tulis atau dalam buku paket matematika, dan hampir tidak pernah mendapat kesempatan untuk apa konsep trigonometri digunakan. Akibatnya banyak siswa yang berpendapat bahwa konsep-konsep trigonometri sangat sukar dipelajari, selain rumus yang juga banyak yang harus dihapalkan. Hasil pada Ujian Nasional tahun 2010/2011, daya serap kemampuan siswa untuk soal materi Trigonometri pokok bahasan rumus-rumus segitiga menunjukkan hasil bahwa penguasaan siswa secara nasional 80,62\%, sementara untuk tingkat Propinsi Jawa Tengah 75,58\% dan khususnya untuk tingkat kabupaten Banyumas hanya $66,80 \%$. Dengan hasil tersebut, ini dapat memberi gambaran bahwa Trigonometri termasuk materi yang belum dikuasai dengan baik oleh siswa-siswa SMA di kabupaten Banyumas.

Model pembelajaran kooperatif TGT merupakan jenis pembelajaran kooperatif yang dirancang untuk memunculkan dinamika kelompok kohesif dan kompak serta tumbuh rasa kompetisi antar kelompok, suasana diskusi nyaman dan menyenangkan seperti dalam kondisi permainan (games). Guru memilih TGT untuk membandingkan kerja kelompok secara keseluruhan. Model pembelajaran kooperatif dengan tipe TGT merupakan salah satu metode pembelajaran yang yang dirancang untuk memunculkan dinamika kelompok serta menumbuhkan rasa berkompetisi antar kelompok, suasana diskusi yang nyaman dan menyenangkan seperti dalam kondisi permainan (games).

Buzan (dalam Brinkmann, 2003:23) mengemukakan bahwa otak manusia bekerja mengolah informasi melalui mengamati, membaca, atau mendengar tentang sesuatu hal berbentuk hubungan fungsional antar bagian (konsep, kata kunci), tidak parsial terpisah satu sama lain dan tidak pula dalam bentuk narasi kalimat lengkap. Selanjutnya Buzan mengemukakan bahwa cara belajar siswa yang alami (natural) adalah sesuai dengan cara kerja otak seperti di atas berupa pikiran. Cara mengolah informasi yang diterima dapat menggunakan peta konsep. Peta konsep bertujuan mereview pengetahuan awal siswa dan mengolah informasi yang ada dalam bentuk catatan gambar yang menarik.

Strategi TGT merupakan suatu cara paling efektif dan menyenangkan untuk membuat variasi suasana diskusi kelas. Model pembelajaran kooperatif TGT dengan peta konsep bertujuan mereview pengetahuan awal siswa. Sintaknya adalah: informasi kompetensi, sajian permasalahan terbuka, siswa berkelompok untuk menanggapi dan membuat berbagai alternatif jawaban, presentasi hasil diskusi kelompok, siswa membuat kesimpulan dari hasil setiap kelompok, evaluasi dan refleksi. Sangat baik digunakan 
untuk pengetahuan awal siswa atau untuk menemukan alternatif jawaban. Perbedaan model pembelajaran kooperatif TGT dengan peta konsep dengan model pembelajaran kooperatif TGT adalah terletak pada langkah awal dan akhir pembelajaran dimana siswa menggali, mengolah dan memahami materi dengan catatan peta konsepnya masingmasing. Dengan mengunakan TGT peta konsep suasana belajar dapat lebih menyenangkan bagi siswa karena siswa bekerja mengolah informasi menurut kemampuannya masing-masing.

Keberhasilan seseorang dalam kehidupannya ternyata tidak hanya ditentukan oleh tingginya tingkat kecerdasan intelektulnya saja, tetapi juga didukung oleh kecerdasan emosional dan kecerdasan spiritualnya. Kemampuan akademik, nilai rapor, predikat kelulusan, tidak bisa dijadikan tolok ukur seberapa baik kinerja seseorang setelah bekerja atau seberapa tinggi sukses yang akan dicapai (Ary Ginanjar Agustian, 2003:56). Goleman (dalam Irvan Ronny, 2012) mengemukakan bahwa struktur otak terbagi dua menjadi kecerdasan intelektual pada otak kiri dan kecerdasan emosional pada otak kanan. Kecerdasan emosional dan spiritual merupakan kemampuan yang dimiliki seseorang dalam mengenali perasaan sendiri dan perasaan orang lain, memotivasi diri sendiri, mengolah emosi dengan baik pada diri sendiri dan orang lain, serta kemampuan seseorang untuk mengerti dan menerima makna pada apa yang dihadapi dalam kehidupan.

Keberhasilan pembelajaran, selain dipengaruhi oleh metode yang digunakan oleh guru juga dipengaruhi faktor dalam diri siswa yaitu konsep diri siswa. Kepercayaan diri siswa akan kemampuannya mendorong siswa untuk selalu berusaha mengaktualisasikan potensi pribadinya. Konsep diri siswa dibentuk oleh pengalaman belajar di sekolah, keluarga dan masyarakat. Latar belakang pengalaman siswa, motivasi keluarga dan lingkungan pergaulan siswa di masyarakat turut membentuk konsep diri siswa. Beragamnya konsep diri dalam satu kelas sangat menarik untuk diteliti sebagai faktor yang mempengaruhi keberhasilan belajar. Konsep diri merupakan cara pandang siswa terhadap dirinya yang merupakan gabungan dari keyakinan tentang dirinya sendiri, karakter fisik, psikologis, sosial, emosional, dan prestasi (Clara Pudjijogyanti, 1998).

Konsep diri yang dimiliki siswa dimungkinkan mempengaruhi kecerdasan emosional dan spiritual masing-masing individu yang akan mempengaruhi seseorang dalam bekerjasama secara kelompok. Setiap individu memiliki cara pandang yang akan menjadi ciri khas dirinya dalam proses pembelajaran yang dilakukan. Siswa dengan konsep diri positif atau negatif dapat membentuk kecerdasan emosional dan spiritual tinggi atau rendah, yang memungkinkan membawa pengaruh terhadap prestasi belajar siswa. 
Berdasarkan latar belakang di atas, dapat dirumuskan masalah sebagai berikut: (1) manakah yang menghasilkan prestasi belajar matematika lebih baik antara siswa yang diberi pembelajaran kooperatif tipe TGT dengan peta konsep, pembelajaran kooperatif tipe TGT, atau pembelajaran konvensional. (2) manakah yang menghasilkan prestasi belajar matematika lebih baik antara siswa yang memiliki kecerdasan emosional spiritual tinggi atau rendah. (3) manakah yang menghasilkan prestasi belajar matematika lebih baik antara siswa yang memiliki konsep diri positif atau negatif. (4) manakah yang lebih baik prestasi belajar matematika siswa yang diberi pembelajaran kooperatif tipe TGT dengan peta konsep, pembelajaran kooperatif tipe TGT, dan pembelajaran konvensional pada siswa yang memiliki kecerdasan emosional spiritual tinggi atau rendah. (5) manakah yang lebih baik prestasi belajar matematika siswa yang diberi pembelajaran kooperatif tipe TGT dengan peta konsep, pembelajaran kooperatif tipe TGT, dan pembelajaran konvensional pada siswa yang memiliki konsep diri positif atau negatif. (6) manakah yang lebih baik prestasi belajar matematika siswa pada masing-masing kategori kecerdasan emosional spiritual (tinggi atau rendah) dan kategori konsep diri (positif atau negatif). (7) manakah yang lebih baik, prestasi belajar matematika siswa pada masingmasing kategori kecerdasan emosional spiritual (tinggi atau rendah) dan kategori konsep diri (positif atau negatif) pada tipe TGT dengan peta konsep, pembelajaran kooperatif tipe TGT, dan pembelajaran konvensional.

\section{METODE PENELITIAN}

Penelitian ini merupakan penelitian eksperimental semu (quasi-experimental research) yaitu peneliti tidak memungkinkan untuk memanipulasi dan atau mengendalikan semua variabel yang relevan dengan rancangan faktorial $3 \times 2 \times 2$. Menurut Budiyono (2003) tujuan eksperimental semu adalah untuk memperoleh informasi yang merupakan perkiraan bagi informasi yang dapat diperoleh dengan eksperimen yang sebenarnya dalam keadaan yang tidak memungkinkan untuk mengontrol dan atau memanipulasi semua variabel yang relevan. Populasi penelitian ini adalah pada siswa kelas XI IA SMA/MA Negeri se-Kabupaten Banyumas tahun pelajaran 2012/2013. Penelitian ini dilaksanakan di SMA N 2 Purwokerto, untuk kelompok atas, SMA N 1 Sokaraja, untuk kelompok tengah dan MAN Purwokerto 2 untuk kelompok bawah. Dari masing-masing sekolah diambil secara acak masing-masing 3 kelas, yaitu satu kelas untuk kelas eksperimen I (Model pembelajaran TGT dengan peta konsep), satu kelas eksperimen II (Model pembelajaran Model pembelajaran TGT) dan satu kelas untuk kelas kontrol (Model pembelajaran konvensional). Variabel bebas dalam penelitian ini adalah model pembelajaran, kecerdasan emosional spiritual (ESQ) yang 
dikelompokkan menjadi 2 kategori ESQ dan ESQ rendah, dan konsep diri siswa yang dikelompokkan menjadi 2 kategori konsep diri positif dan konsep diri negatif. Sedangkan variabel terikat dalam penelitian ini adalah prestasi belajar matematika pada pokok bahasan Trigonometri Rumus Jumlah dan Selisih Dua Sudut. Teknik pengumpulan data dalam penelitian ini adalah menggunakan (1) metode dokumentasi; (2) metode tes; (3) metode angket. Instrumen penelitian terdiri atas tes prestasi belajar matematika, angket kecerdasan emosional spiritual dan angket konsep diri siswa.

Analisis data dilakukan menggunakan analisis variansi tiga jalan dengan sel tak sama. Sebelum analisis dilakukan uji prasyarat analisis variansi yaitu uji Normalitas menggunakan Uji Lilliefors, Uji Homogenitas menggunakan Uji Bartlett, Uji keseimbangan menggunakan analisis variansi satu jalan dengan sel tak sama. Dari hasil uji diperoleh masing-masing kelompok berdistribusi normal, dan berasal dari populasi yang homogen serta memiliki kemampuan awal yang sama.

\section{HASIL PENELITIAN DAN PEMBAHASAN}

Hasil uji keseimbangan kemampuan awal yang telah dilakukan terhadap kelas eksperimen dan kelas kontrol diperoleh $F_{\text {hitung }}=2,72$ dan $F_{\text {tabel }}=3,00$. Dengan demikian diperoleh keputusan uji yang menyatakan $\mathrm{H}_{0}$ tidak ditolak $\left(\mathrm{H}_{0}\right.$ diterima). Ini berarti ketiga populasi mempunyai kemampuan awal yang seimbang.

Deskripsi data sampel prestasi belajar matematika siswa berdasarkan model pembelajaran, tingkat kecerdasan ESQ dan konsep diri dapat dilihat pada Tabel 1.

Tabel 1. Deskriptif Data Tes Prestasi Belajar Siswa

\begin{tabular}{|c|c|c|c|c|c|c|c|}
\hline Model & ESQ & $\begin{array}{l}\text { Konsep } \\
\text { Diri }\end{array}$ & $\begin{array}{c}\text { Jumlah } \\
\text { Siswa }\end{array}$ & $x_{\max }$ & $x_{\min }$ & Rerata & Standar Deviasi \\
\hline \multirow{4}{*}{$\begin{array}{c}\text { Tipe TGT } \\
\text { dengan Peta } \\
\text { Konsep }\end{array}$} & \multirow[b]{2}{*}{ Tinggi } & Positif & 30 & 100 & 70 & 89 & 9,04 \\
\hline & & Negatif & 12 & 90 & 60 & 75 & 8,79 \\
\hline & \multirow{2}{*}{ Rendah } & Positif & 9 & 100 & 85 & 93,89 & 4,86 \\
\hline & & Negatif & 24 & 90 & 50 & 70,42 & 13,51 \\
\hline \multirow{4}{*}{ Tipe TGT } & \multirow{2}{*}{ Tinggi } & Positif & 33 & 100 & 45 & 70,76 & 17,14 \\
\hline & & Negatif & 18 & 80 & 30 & 59,44 & 18,14 \\
\hline & \multirow{2}{*}{ Rendah } & Positif & 15 & 90 & 60 & 67,33 & 11,93 \\
\hline & & Negatif & 21 & 100 & 50 & 65,24 & 17,21 \\
\hline \multirow{4}{*}{$\begin{array}{c}\text { Model } \\
\text { Konvensional }\end{array}$} & \multirow{2}{*}{ Tinggi } & Positif & 18 & 95 & 40 & 72,5 & 18,01 \\
\hline & & Negatif & 18 & 90 & 35 & 70,28 & 20,03 \\
\hline & \multirow{2}{*}{ Rendah } & Positif & 18 & 85 & 50 & 70 & 13,93 \\
\hline & & Negatif & 33 & 90 & 35 & 65,3 & 17,63 \\
\hline
\end{tabular}

Dari deskripsi data diatas, dapat dilihat masih ada siswa yang mendapat nilai cukup rendah baik pada siswa yang menggunakan model pembelajaran TGT maupun konvensional, tetapi pada kelompok siswa yang menggunakan TGT dengan peta konsep relatif memiliki nilai yang sudah cukup baik. 
Berdasarkan uji analisis variansi tiga jalan dengan sel tak sama yang dilakukan terhadap tiga faktor variabel bebas yaitu model pembelajaran, kecerdasan emosional spiritual dan konsep diri, interaksi model pembelajaran dengan kecerdasan emosional spiritual, model pembelajaran dengan konsep diri, kecerdasan emosional spiritual dengan konsep diri, dan model pembelajaran, kecerdasan emosional dan konsep diri terhadap prestasi belajar dapat dilihat pada Tabel 2 .

Tabel 2. Rangkuman Hasil Analisis Variansi Tiga Jalan Sel Tak Sama

\begin{tabular}{ccccccc}
\hline Sumber & JK & dk & RK & F obs & F tabel & Keputusan \\
\hline A & 10579,32 & 2 & 5289,66 & 22,34 & 3 & $\mathrm{H}_{0 \mathrm{~A}}$ Ditolak \\
B & 34,56 & 1 & 34,56 & 0,15 & 3,84 & $\mathrm{H}_{0 \mathrm{~B}}$ Diterima \\
C & 5011,2 & 1 & 5011,2 & 21,17 & 3,84 & $\mathrm{H}_{0 \mathrm{C}}$ Ditolak \\
AB & 243 & 2 & 121,5 & 0,51 & 3 & $\mathrm{H}_{0 \mathrm{AB}}$ Diterima \\
AC & 2331,54 & 2 & 1165,77 & 4,92 & 3 & $\mathrm{H}_{0 \mathrm{AC}}$ Ditolak \\
BC & 11,16 & 1 & 11,16 & 0,05 & 3,84 & $\mathrm{H}_{0 \mathrm{BC}}$ Diterima \\
ABC & 803,34 & 2 & 401,67 & 1,7 & 3 & $\mathrm{H}_{0 \mathrm{ABC}}$ Diterima \\
Galat & 56105,44 & 237 & 236,7318 & & & \\
Total & 75119,56 & 248 & & & & \\
\hline
\end{tabular}

Berdasarkan hasil uji hipotesis kemudian dilakukan uji lanjut pasca anava. Metode yang digunakan pada uji lanjut pasca Anava adalah metode Scheffe. Hasil uji komparasai ganda pada model pembelajaran terlihat pada Tabel 3.

Tabel 3. Rangkuman Uji Komparasi Ganda pada Interaksi Model Pembelajaran

\begin{tabular}{ccccl}
\hline No & Komparasi & $\mathrm{F}_{\text {hitung }}$ & $\mathrm{F}_{\text {tabel }}$ & Keputusan Uji \\
\hline 1. & $\mu_{1 .}$ vs $\mu_{2}$. & 35,9601 & 6 & $\mathrm{H}_{0}$ ditolak \\
2. & $\mu_{1 .}$ vs $\mu_{3 .}$ & 25,7215 & 6 & $\mathrm{H}_{0}$ ditolak \\
3. & $\mu_{2 .}$ vs $\mu_{3 .}$ & 0,9242 & 6 & $\mathrm{H}_{0}$ diterima \\
\hline
\end{tabular}

Untuk mengetahui hubungan efek antara kategori model pembelajaran dan kategori konsep diri perlu dilakukan uji lanjut pasca Anava. Metode yang digunakan pada uji lanjut pasca Anava adalah metode Scheffe. Hal ini berarti perlu dilakukan komparasi rerata antar baris dan antar kolom. Hasil uji komparasai ganda Tabel 4.

Tabel 4. Rangkuman Uji Komparasi Ganda Antar Sel pada Interaksi Model Pembelajaran dan Konsep Diri Siswa

\begin{tabular}{ccccl}
\hline No & Komparasi & $F_{\text {hitung }}$ & $F_{\text {tabel }}$ & Keputusan Uji \\
\hline 1. & $\mu_{11}$ vs $\mu_{12}$ & 24,8755 & 11,05 & $H_{0}$ ditolak \\
2. & $\mu_{21}$ vs $\mu_{22}$ & 4,3931 & 11,05 & $H_{0}$ diterima \\
3. & $\mu_{31}$ vs $\mu_{32}$ & 1,4879 & 11,05 & $H_{0}$ diterima \\
4. & $\mu_{11}$ vs $\mu_{21}$ & 36,1035 & 11,05 & $H_{0}$ ditolak \\
5. & $\mu_{11} \operatorname{vs} \mu_{31}$ & 26,7985 & 11,05 & $H_{0}$ ditolak \\
6. & $\mu_{21} \operatorname{vs~} \mu_{31}$ & 0,2011 & 11,05 & $H_{0}$ diterima \\
7. & $\mu_{12} \operatorname{vs} \mu_{22}$ & 6,6147 & 11,05 & $H_{0}$ diterima \\
8. & $\mu_{12} \operatorname{vs~} \mu_{32}$ & 2,0183 & 11,05 & $H_{0}$ diterima \\
9. & $\mu_{22} \operatorname{vs} \mu_{32}$ & 1,7973 & 11,05 & $H_{0}$ diterima \\
\hline
\end{tabular}

Dari hasil uji anava tiga jalan dan uji lanjut pasca aanava, diperoleh hasil sebagai berikut : 
1. Berdasarkan uji anava pada Tabel 2 diperoleh bahwa $H_{O A}$ ditolak. Hal ini berarti siswa yang diberi perlakuan model TGT dengan peta konsep memiliki prestasi belajar yang berbeda dari siswa yang diberi perlakuan model TGT maupun konvensional pada pembelajaran materi rumus jumlah dan selisih dua sudut. Dari rangkuman komparasi rerata antar baris pada Tabel 3 diperoleh pada penerapan model TGT dengan Peta Konsep dan model TGT diperoleh $F_{1 . \sim 2 .}=35,9601$ dan $D K$ $=\{F \mid F>6\}$. Dengan demikian, $F_{1, \sim 2} \in D K$ dan keputusan ujinya adalah $H_{0}$ ditolak. Berdasarkan keputusan uji tersebut dan melihat rerata maka model TGT dengan peta konsep memberikan prestasi belajar yang lebih baik dibandingkan dengan model TGT. Pada penerapan model TGT dengan peta konsep dan model konvensional diperoleh $F_{1 . \sim 3 .}=25,7215$ dan $D K=\{F \mid F>6\}$. Dengan demikian, $F_{1.3 .} \in D K$ dan keputusan ujinya adalah $H_{0}$ ditolak. Berdasarkan keputusan uji tersebut dan melihat rerata maka model pembelajaran konvensional memberikan prestasi belajar yang lebih baik dibandingkan dengan model TGT. Pada penerapan model TGT dan model konvensional diperoleh $F_{2 \sim 3}=0,9242$ dan $D K=\{F \mid F>6\}$. Dengan demikian, $F_{2, \sim 3 .} \notin D \mathrm{~K}$ dan keputusan ujinya adalah $H_{0}$ diterima. Berdasarkan keputusan uji tersebut maka model TGT memberikan prestasi belajar yang sama dengan model konvensional. Dapat disimpulkan prestasi belajar matematika siswa dengan model TGT dengan peta konsep lebih baik dari siswa dengan model TGT maupun model konvensional. Tetapi tidak ada perbedaan prestasi belajar antara siswa dengan model konvensional maupun model TGT.

Faktor yang menyebabkan prestasi belajar siswa yang diberikan model TGT dengan peta konsep lebih baik dari model TGT maupun konvensional dimungkinkan karena ketertarikan siswa dalam membuat catatan sesuai dengan dirinya sendiri sehingga siswa lebih kreatif dan menarik untuk belajar matematika. Adapun faktor yang menyebabkan prestasi belajar matematika siswa yang diberi model konvensional lebih baik daripada model TGT dimungkinkan karena kurang maksimal pada tahap diskusi kelompok dan pelaksanaan mengerjakan soal kuis dalam permainan.

Hipotesis ini sesuai dengan hasil penelitian yang dilakukan oleh Brinkmann (2003) yang menyatakan metode pemetaan pikiran dan pemetaan konsep tidak ditemukan sebagai alat pendidikan, tetapi ditemukan sebagai metode yang berguna dalam berbagai aplikasi dalam proses belajar mengajar. Demikian juga dengan penelitian yang dilakukan oleh Iwit Prihatin (2012) yang menyatakan bahwa model pembelajaran Teams Games Tournament (TGT) dengan pendekatan kontekstual memberikan hasil prestasi belajar yang lebih baik daripada model pembelajaran TGT 
tanpa pendekatan kontekstual, sehingga bagi siswa materi pokok bahasan trigonometri kesulitannya terletak pada banyaknya rumus yang harus dihapalkan, sehingga model pembelajaran yang menarik sangat cocok diterapkan untuk lebih memaksimalkan hasil belajar siswa.

2. Dari hasil uji anava pada Tabel 2 diperoleh bahwa $H_{O B}$ diterima. Hal ini berarti tidak terdapat perbedaan prestasi belajar matematika siswa dengan ESQ tinggi dengan siswa dengan ESQ rendah. Dengan kata lain siswa dengan ESQ tinggi dan siswa dengan ESQ rendah memiliki prestasi belajar matematika yang sama. Ada kemungkinan hal ini disebabkan pada pokok bahasan yang dipelajari, sehingga dalam penerapan model-model pembelajaran ini cenderung sama, juga pada proses pembelajaran guru kurang maksimal dalam menerapkan masing-masing model dikarenakan guru kurang memahami proses pembelajaran yang ada dalam RPP, sehingga diskusi kelompok tidak dapat berjalan maksimal, dimana pada tahap ini seharusnya dibutuhkan kecerdasan emosional spiritual dalam melaksanakan diskusi kelompok. Tetapi itu juga dimungkinkan bahwa dalam membuat peta konsep dalam bentuk gambar tidak terlalu diperlukan kecerdasan emosional spiritual, sehingga model pembelajaran apapun tidak memberi pengaruh yang signifikan terhadap hasil belajar matematika siswa.

3. Berdasarkan uji anava pada Tabel 2 diperoleh bahwa $H_{O C}$ ditolak. Hal ini berarti siswa dengan konsep diri positif memiliki prestasi belajar matematika yang berbeda dari siswa dengan konsep diri negatif. Dengan kata lain konsep diri positif dan konsep diri negatif berpengaruh terhadap prestasi belajar siswa. Berdasarkan rerata siswa yang memiliki konsep diri positif sebesar 76,63 sedangkan rerata siswa yang memiliki konsep diri negatif sebesar 67,06. Artinya konsep diri positif memberikan prestasi belajar yang lebih baik dibandingkan dengan konsep diri negatif. Kesesuaian hasil penelitian dengan hipotesis disebabkan karena konsep diri merupakan ciri seseorang. Siswa dengan konsep diri positif memiliki optimisme dan keyakinan yang tinggi, optimis dalam berkompetisi, mampu menerima tantangan, sehingga sifat ini akan membentuk siswa menjadi pribadi yang percaya diri sehingga mereka lebih mudah dalam menerima materi pelajaran dan pribadi yang penuh perhatian akan mudah mengingat materi pelajaran yang diberikan oleh guru. Sehingga dalam pokok bahasan trigonometri siswa yang memiliki konsep diri baik juga akan mendapatkan hasil yang lebih baik juga. Alison Clarke-Stewart (dalam Aristorahadi, 2008) berpendapat bahwa anak yang memiliki konsep diri positif akan mengembangkan rasa percaya diri; sedikit perasaan rendah diri dan mampu untuk melihat diri sendiri secara realistis; bersifat defensif seperti malu dan menarik diri serta memiliki harga 
diri yang tinggi. Anak yang memiliki konsep diri negatif akan mengembangkan penyesuaian sosial yang kurang baik, mengalami perasaan yang tidak menentu, inferioritas, menggunakan banyak mekanisme pembelaan, dan memiliki level harga diri yang rendah. Sehingga konsep diri yang dimiliki siswa sangat berperan dan berpengaruh terhadap kegiatan belajar dan diskusi yang dilakukan.

4. Berdasarkan uji anava pada Tabel 2 diperoleh bahwa $H_{O A B}$ diterima. Berarti tidak terdapat interaksi antara model pembelajaran dan kecerdasan emosional spiritual siswa terhadap prestasi belajar matematika. Tidak terdapatnya interaksi ini dapat dilihat dari kenyataan bahwa hipotesis kedua $H_{O B}$ diterima. Pengaruh variabel model pembelajaran terhadap variabel terikat prestasi belajar tidak tergantung pada kategori variabel kecerdasan emosional spiritual. Hal ini berarti antara model pembelajaran dan kecerdasan emosional spiritual tidak memiliki keterkaitan yang signifikan yang mempengaruhi prestasi belajar matematika siswa. Hal ini dimungkinkan karena materi pokok bahasan trigonometri yang lebih banyak rumus yang harus dihapalkan secara individu, sehingga model pembelajaran TGT yang dapat memunculkan kemandirian, kecerdasan dan kreatif siswa tidak dapat optimal dilakukan pada diskusi kelompok. Kecerdasan emosional spiritual yang mencakup bagaimana siswa mengenali, mengelola, memotivasi emosi dirinya dan mengenali emosi orang lain untuk kemudian membina hubungan dengan orang lain dan bekerjasama dalam kegiatan belajar seharusnya harus dimunculkan dan dikembangkan oleh guru. Seringkali dalam kegiatan belajar dan diskusi kelompok ditemukan siswa yang memiliki kecerdasan intelektual tinggi cenderung memiliki keegoisan yang tinggi untuk berbagi pada teman dalam kelompoknya sehingga diskusi kelompok tidak berjalan maksimal, atau sebaliknya siswa yang memiliki kecerdasan intelektual yang biasa saja justru memiliki kepekaan dan empati yang baik terhadap temannya sehingga diskusi bisa berjalan dengan baik. Hal ini mungkin yang menyebabkan tidak ada perbedaan hasil belajar matematika siswa yang memiliki kecerdasan emosional spiritual tinggi dengan siswa yang memiliki kecerdasan emosional spiritual rendah. Diharapkan guru dapat lebih memperhatikan aspek pengembangan diri siswa sehingga hasil belajar dapat lebih maksimal.

5. Berdasarkan uji anava tiga jalan pada Tabel 2 diperoleh bahwa $H_{O A C}$ ditolak. Berarti terdapat interaksi antara model pembelajaran dan konsep diri siswa terhadap prestasi belajar matematika. Terdapatnya interaksi ini menunjukkan ada pengaruh hubungan yang signifikan antara model pembelajaran dan konsep diri terhadap prestasi belajar matematika siswa. Hal ini berarti antara model pembelajaran dan konsep diri memiliki keterkaitan yang signifikan yang mempengaruhi prestasi belajar 
matematika siswa. Dengan kata lain pada masing-masing pada model pembelajaran, siswa dengan konsep diri positif memiliki prestasi belajar yang berbeda dari siswa dengan konsep diri negatif. Demikian pula pada masing-masing konsep diri, siswa yang beri model TGT dengan peta konsep, TGT maupun konvensional memiliki prestasi belajar yang berbeda.

Dari rangkuman komparasi ganda antar sel pada interaksi model pembelajaran dan konsep diri siswa pada tabel 4 diperoleh pada penerapan model TGT dengan peta konsep dengan konsep diri positif dan model TGT dengan peta konsep dengan konsep diri negatif diperoleh $F_{11 \sim 12}=24,8755$ dan $D K=\{F \mid F>11,05\}$. Dengan demikian, $F_{11 \sim 12} \in D K$ dan keputusan ujinya adalah $H_{0}$ ditolak. Berdasarkan keputusan uji tersebut dan melihat rerata maka penerapan model TGT dengan peta konsep dengan konsep diri positif memberikan prestasi belajar yang lebih baik dibandingkan dengan model TGT dengan peta konsep dengan konsep diri negatif. Pada penerapan model TGT dengan konsep diri positif dan model TGT dengan konsep diri negatif diperoleh $F_{21 \sim 22}=4,3931$ dan $D K=\{F \mid F>11,05\}$. Dengan demikian, $F_{11 \sim 12} \notin D K$ dan keputusan ujinya adalah $H_{0}$ diterima. Berdasarkan keputusan uji tersebut maka penerapan model TGT dengan konsep diri positif memberikan prestasi belajar yang sama dengan model TGT dengan konsep diri negatif. Pada penerapan model konvensional dengan konsep diri positif dan model konvensional dengan konsep diri negatif diperoleh $F_{31 \sim 32}=1,4879$ dan $D K=\{F \mid F$ $>11,05\}$. Dengan demikian, $F_{31 \sim 32} \notin D K$ dan keputusan ujinya adalah $H_{0}$ diterima. Berdasarkan keputusan uji tersebut maka penerapan model konvensional dengan konsep diri positif memberikan prestasi belajar yang sama dengan model konvensional dengan konsep diri negatif.

Pada penerapan model TGT dengan peta konsep dengan konsep diri positif dan model TGT dengan konsep diri positif diperoleh $F_{11 \sim 21}=36,1035$ dan $D K=$ $\{F \mid F>11,05\}$. Dengan demikian, $F_{11 \sim 21} \in D K$ dan keputusan ujinya adalah $H_{0}$ ditolak. Berdasarkan keputusan uji tersebut dan melihat rerata maka penerapan model TGT dengan peta konsep dengan konsep diri positif memberikan prestasi belajar yang lebih baik dibandingkan dengan model TGT dengan konsep diri positif. Pada penerapan model TGT dengan peta konsep dengan konsep diri positif dan model konvensional dengan konsep diri positif diperoleh $F_{11 \sim 31}=26,7985$ dan $D K=$ $\{F \mid F>11,05\}$. Dengan demikian, $F_{11 \sim 31} \in D K$ dan keputusan ujinya adalah $\mathrm{H}_{0}$ ditolak. Berdasarkan keputusan uji tersebut dan melihat rerata maka penerapan model TGT dengan peta konsep dengan konsep diri positif memberikan prestasi 
belajar yang lebih baik dibandingkan dengan model konvensional dengan konsep diri positif.

Pada penerapan model TGT dengan konsep diri positif dan model konvensional dengan konsep diri positif diperoleh $F_{21 \sim 31}=0,2011$ dan $D K=\{F|F\rangle$ $11,05\}$. Dengan demikian, $F_{21 \sim 31} \notin D K$ dan keputusan ujinya adalah $H_{0}$ diterima. Berdasarkan keputusan uji tersebut maka penerapan model TGT dengan konsep diri positif memberikan prestasi belajar yang sama dengan model konvensional dengan konsep diri positif. Pada penerapan model TGT dengan peta konsep dengan konsep diri negatif dan model TGT dengan konsep diri negatif diperoleh $F_{12 \sim 22}=6,6147$ dan $D K=\{F \mid F>11,05\}$. Dengan demikian, $F_{12 \sim 22} \notin D K$ dan keputusan ujinya adalah $H_{0}$ diterima. Berdasarkan keputusan uji tersebut maka penerapan model TGT dengan peta konsep dengan konsep diri negatif memberikan prestasi belajar yang sama dengan model TGT dengan konsep diri negatif. Pada penerapan model TGT dengan peta konsep dengan konsep diri negatif dan model konvensional dengan konsep diri negatif diperoleh $F_{12 \sim 32}=2,0183$ dan $D K=\{F \mid F>11,05\}$. Dengan demikian, $F_{12 \sim 32} \notin D K$ dan keputusan ujinya adalah $H_{0}$ diterima. Berdasarkan keputusan uji tersebut maka penerapan model TGT dengan peta konsep dengan konsep diri negatif memberikan prestasi belajar yang sama dengan model konvensional dengan konsep diri negatif. Pada penerapan model TGT dengan konsep diri negatif dan model konvensional dengan konsep diri negatif diperoleh $F_{22 \sim 32}=11,05$ dan $D K=\{F \mid F>11,05\}$. Dengan demikian, $F_{22 \sim 32} \notin D K$ dan keputusan ujinya adalah $H_{0}$ diterima. Berdasarkan keputusan uji tersebut maka penerapan model TGT dengan konsep diri negatif memberikan prestasi belajar yang sama dengan model konvensional dengan konsep diri negatif.

Hal ini sesuai dengan teori yang ada bahwa model TGT yang dapat memunculkan kemandirian, kecerdasan dan kreatif siswa serta peta konsep membutuhkan kreatifitas setiap individu siswa. Siswa dengan konsep diri positif memberikan prestasi belajar lebih baik daripada siswa dengan konsep diri negatif dikarenakan peta konsep siswa sesuai dengan kemampuan dirinya dalam memahami materi yang diberikan. Dapat disimpulkan prestasi belajar matematika siswa pada model TGT dengan peta konsep, siswa dengan konsep diri positif memberikan prestasi hasil belajar matematika lebih baik dari siswa dengan konsep diri negatif, sedangkan pada model TGT maupun konvensional, tidak ada perbedaan prestasi belajar antara siswa dengan konsep diri negatif maupun siswa dengan konsep diri negatif. Pada siswa dengan konsep diri negatif, prestasi belajar siswa dengan model TGT dengan peta konsep lebih baik daripada model TGT maupun konvensional, 
tetapi tidak ada perbedaan prestasi belajar siswa antara model TGT dengan model konvensional. Sedangkan pada siswa dengan konsep diri negatif tidak ada perbedaan prestasi belajar siswa antara model TGT dengan peta konsep, TGT maupun konvensional.

6. Berdasarkan uji anava tiga jalan pada Tabel 2 diperoleh bahwa $H_{O B C}$ diterima. Berarti tidak terdapat interaksi antara kecerdasan emosional spiritual dan konsep diri siswa terhadap prestasi belajar matematika. Tidak terdapatnya interaksi ini dapat dilihat dari kenyataan bahwa hipotesis kedua $H_{0 B}$ diterima. Pengaruh variabel ESQ terhadap variabel terikat prestasi belajar tidak tergantung pada kategori variabel konsep diri. Di sisi lain pengaruh variabel konsep diri terhadap variabel terikat prestasi belajar tidak tergantung pada kategori variabel ESQ. Pada setiap tingkat kecerdasan emosional spirtual siswa dengan konsep diri positif memiliki prestasi belajar matematika yang berbeda dari siswa dengan konsep diri negatif. Hal ini dimungkinkan karena siswa dengan konsep diri positif memiliki sifat merasa setara dengan orang lain, sanggup menerima dirinya sebagai orang yang bernilai bagi orang lain, merasa yakin dengan kemampuan yang dimiliki, optimis terhadap kompetisi, mampu menerima tantangan, peka akan kebutuhan orang lain dan penuh perhatian. Sifat ini akan membentuk siswa menjadi pribadi yang memiliki kecerdasan emosional spiritual yang tinggi pula. Semakin positif konsep diri yang dimiliki akan membentuk kecerdasan emosional dan spiritual yang tinggi. Sehingga antara konsep diri dan kecerdasan emosional spiritual berbanding lurus.

7. Berdasarkan uji anava tiga jalan pada Tabel 2 diperoleh bahwa $H_{O A B C}$ diterima. Berarti tidak terdapat interaksi antara model pembelajaran, kecerdasan emosional spiritual dan konsep diri siswa terhadap prestasi belajar matematika. Tidak terdapatnya interaksi ini dapat dilihat dari kenyataan bahwa variabel model pembelajaran terhadap variabel terikat prestasi belajar tidak tergantung pada kategori variabel ESQ, dan variabel ESQ terhadap variabel terikat prestasi belajar tidak tergantung pada kategori variabel konsep diri. Hal ini dimungkinkan karena siswa yang memiliki ESQ tinggi memiliki kemandirian yang tinggi pula sehingga dalam diskusi kelompok tidak berjalan maksimal sehingga model pembelajaran yang diberikan tidak terlalu berpengaruh terhadap hasil belajar matematika siswa.

\section{KESIMPULAN DAN SARAN}

Berdasarkan hasil analisis data yang telah dilakukan, maka dapat disimpulkan bahwa: 
1. Prestasi belajar matematika siswa dengan model TGT dengan peta konsep lebih baik dari siswa dengan model TGT maupun siswa dengan model konvensional. Tetapi tidak ada perbedaan prestasi belajar antara siswa dengan model konvensional maupun siswa dengan model TGT.

2. Tidak ada perbedaan prestasi belajar matematika siswa dengan ESQ tinggi dengan siswa dengan ESQ rendah.

3. Prestasi belajar matematika siswa dengan konsep diri positif lebih baik dari siswa dengan konsep diri negatif.

4. Pada setiap model pembelajaran baik itu TGT dengan peta konsep, TGT maupun konvensional, siswa dengan ESQ tinggi selalu memberikan prestasi belajar yang lebih baik daripada siswa dengan ESQ rendah. Demikian juga pada setiap tingkat ESQ, model pembelajaran TGT dengan peta konsep selalu memberikan prestasi belajar yang lebih baik dari model TGT maupun model konvensional, dan model konvensional memberikan prestasi belajar yang lebih baik dari model TGT.

5. Prestasi belajar matematika siswa pada model TGT Peta Konsep, siswa dengan konsep diri positif memberikan prestasi hasil belajar matematika lebih baik dari siswa dengan konsep diri negatif, sedangkan pada model TGT maupun konvensional, tidak ada perbedaan prestasi belajar antara siswa dengan konsep diri positif maupun siswa dengan konsep diri negatif. Pada siswa dengan konsep diri positif, prestasi belajar siswa dengan model TGT dengan peta konsep lebih baik daripada model TGT maupun konvensional, tetapi tidak ada perbedaan prestasi belajar siswa antara model TGT dengan model konvensional. Sedangkan pada siswa dengan konsep diri negatif tidak ada perbedaan prestasi belajar siswa antara model TGT Peta Konsep, TGT maupun konvensional.

6. Pada setiap tingkat ESQ baik itu tinggi maupun rendah, siswa dengan konsep diri positif memberikan prestasi belajar yang lebih baik daripada siswa dengan konsep diri negatif. Demikian juga pada setiap tingkat konsep diri baik itu positif maupun negatif, siswa dengan ESQ tinggi memberikan prestasi belajar yang lebih baik daripada siswa dengan ESQ rendah.

7. Tidak ada perbedaan prestasi belajar matematika siswa yang diberikan model pembelajaran baik itu model pembelajaran TGT dengan peta konsep, TGT maupun konvensional pada setiap kecerdasan emosional spiritual dan pada setiap konsep diri siswa.

Berdasarkan simpulan, maka dapat dikemukakan saran sebagai berikut:

1. Bagi Sekolah 
Hendaknya mengadakan kegiatan-kegiatan yang dapat menumbuhkan dan mengembangkan kemampuan siswa untuk lebih mengenal konsep dirinya sehingga proses kegiatan belajar akan lebih baik, menyenangkan dan mencapai tujuannya.

2. Bagi Guru

a. Dalam penyampaian materi pembelajaran matematika, guru dan calon guru bidang studi matematika perlu memperhatikan adanya pemilihan model pembelajaran yang tepat yaitu sesuai dengan materi pada pokok bahasan yang dipelajari. Salah satu alternatif model pembelajaran yang bisa diterapkan adalah pembelajaran matematika dengan model pembelajaran kooperatif tipe Teams Games Tournament (TGT) dengan peta konsep yang dapat mengoptimalkan kemampuan kerja sama dan pembelajaran yang menyenangkan.

b. Dalam kegiatan pembelajaran, hendaknya guru dapat mengembangkan pembelajaran peta konsep dalam pembelajaran matematika pada pokok bahasan lainnya, agar siswa dapat mengembangkan proses berpikir siswa sesuai kemampuan dirinya dalam membuat catatan matematikanya.

c. Dalam kegiatan pembelajaran, hendaknya guru lebih memperhatikan konsep diri siswa sehingga dengan mengenal kemampuan siswanya guru akan membuat skenario pembelajaran yang tepat.

3. Bagi peneliti lain

Walaupun hasil penelitian ini menunjukkan bahwa tidak ada perbedaan prestasi belajar matematika siswa dengan ESQ tinggi dengan siswa dengan ESQ rendah, tetapi beberapa teori dan penelitian menyatakan bahwa kemampuan ESQ mempengaruhi hasil prestasi belajar. Untuk itu peneliti menyarankan diadakan penelitian lebih lanjut dan mendalam tentang kemampuan ESQ dan pengaruhnya terhadap model pembelajaran.

\section{DAFTAR PUSTAKA}

Aristorahadi. 2012. Konsep Diri Dalam Pendidikan. http://aristorahadi.wordpress.com/ 2008/03/31/konsep-diri-dalam-pendidikan/. Februari 2013.

Ary Ginanjar Agustian. 2003. Rahasia Sukses Membangkitkan ESQ Power. Jakarta: Arga.

Brinkmann, A. 2003. Graphical Knowledge Display - Mind Mapping and Concept Mapping as Efficient Tools in Mathematics Education. Journal University of Duisburg, Germany Mathematics Education Review, No 16 (pp. 35-48), April, 2003. 
Brett, D.J. 2012. The Effects of Mind Mapping Activities on Students' Motivation. Journal. International Journal for the Scholarship of Teaching and Learning. Volume 6 No. 1 (pp. 1-4), Januari 2012.

Budiyono, 2003. Metodologi Penelitian Pendidikan, Surakarta : UNS Press.

Clara R.Pudjijogyanti. 1998. Konsep Diri dalam Pendidikan. Jakarta: Arcan.

Irvan Ronny. 2012. Kecerdasan Ganda. http://irvanronny.blogspot.com/. Februari 2013.

Iwit Prihatin. 2012. Eksperimentasi Model Pembelajaran Kooperatif Tipe Teams Games Tournament (TGT) Dengan Pendekatan Konstekstual Pada Materi Pecahan Ditinjau Dari Aspek Afektif Siswa SMP Kabupaten Kayong. Tesis. Prodi Pendidikan Matematika Program Pasca Sarjana UNS, Surakarta.

Ratri Rahayu. 2012. Keefektifan Pembelajaran Kooperatif Model Mind Mapping Berbantuan CD Pembelajaran Terhadap Hasil Belajar. Journal. Unnes Journal of Mathematics Education. http://journal.unnes.ac.id/sju/index.php/ujme. Volume 1 (hal. 1-7). Agustus 2012. 